19. Marulasiddesha, K. N., Sankar, M. and Gouda, R. G. K. R., Screening of sorghum genotypes for resistance to damage caused by the stem borer Chilo partellus (Swinhoe). Spanish J. Agric. Res., 2007, 5(1), 79-81.

20. Mane et al., 2008.

ACKNOWLEDGEMENTS. We are thankful to Directorate of Sorgum research, Rajendranagar, Hyderabad, Telangana state for providing seed material for conducting this research work and providing information on various genotypes which were used in research.

Received 5 September 2018; revised accepted 7 January 2019

doi: $10.18520 / \mathrm{cs} / \mathrm{v} 117 / \mathrm{i} 4 / 692-699$

\section{Burrow morphology of the ocypodid crab Ocypode ceratophthalma at Chandipur Coast, Eastern India and its implications}

\author{
Jyotirmoy Paul ${ }^{1, *}$, Subhronil Mondal ${ }^{2}$, \\ Rishikesh Kayal ${ }^{3}$ and Deepjay Sarkar ${ }^{4}$ \\ ${ }^{1}$ Centre for Earth Sciences, Indian Institute of Science, \\ Bengaluru 560 012, India \\ ${ }^{2}$ Department of Geology, University of Calcutta, 35, B.C. Road, \\ Kolkata 700 019, India \\ ${ }^{3} 461$, P. N. Dey Road, West Rajapur, Kolkata 700 032, India \\ ${ }^{4}$ Department of Geology and Geophysics, \\ Indian Institute of Technology, Kharagpur 721 302, India
}

Several burrow morphological features of crab Ocypode ceratophthalma including burrow diameter, orientation, inclination, branching and volume were studied from Chandipur, a sedimentologically and biologically diverse beach on the eastern Indian coast. Burrow morphologies (e.g. $I, J, Y$ ) were independent of their positions with respect to the coast line. In addition, no correlation between burrow morphology and burrow diameter was observed; however, diameter of burrow appeared to be a good proxy of the total amount of sediment excavated. Burrow diameters are significantly smaller in the foreshore compared to that of the backshore, suggesting that larger individuals reside along the backshore, where they excavate deeper and large-diameter burrows to minimize chances of desiccation. Smaller burrows are more or less vertical, whereas larger burrows are inclined towards the land, probably to stabilize their domicile from tidal

*For correspondence. (e-mail: jyotirmoyp@iisc.ac.in) activities, as well as to minimize energy required to excavate sediments. All these suggest that different types of abiotic factors determine the Ocypode burrow morphology and their habitat segregation.

Keywords: Chandipur, crab burrow morphology, crab energetic, Ocypodidae.

THE semi-terrestrial, burrowing crabs of the family Ocypodidae are most common along almost all the tropical and subtropical coastlines of the world ${ }^{1,2}$. Among them, ghost crabs of the genus Ocypode ${ }^{3}$ are common members of sandy beaches all over the world. They live across a wide range of coastal zones and make characteristic burrows ${ }^{1,2,4,5}$. Burrows made by these crabs mainly act as shelters from natural environmental stress, a refuge from both aerial and terrestrial predators, as well as a place for reproduction and moulting ${ }^{6,7}$. The most characteristic feature of burrows produced by Ocypode spp. is that their burrows are morphologically diverse and vary from simply straight, unbranched, I-shaped burrows grading to more complex, gently curved and branched U, V, and Y-shaped ones to multi-branched, spiral burrows ${ }^{2,8-12}$. Moreover, burrow morphology of these ghost crabs does not vary with $\operatorname{sex}^{8,13}$. Secondly, the spatial distribution of these different types of burrows along the sandy, coastal beaches is non-random depending on burrow diameter, vertical depth, length and orientation. Their complexity increases from the foreshore to the backshore region $^{5,8,9,12,13}$.

These large arrays of burrow morphologies produced by members of the family Ocypodidae are speciesspecific $^{2,7,8,11}$, although they may also depend upon several abiotic/environmental factors, such as geography and geomorphology (slope, vegetation cover, salinity, groundwater table and tidal cycle) and substrate properties (compactness and composition) $)^{5,13-17}$. Other biological factors, like size and ontogeny, can also affect the overall morphology of these burrows ${ }^{5,8,14,15}$. Unfortunately, to-date, there is no consensus regarding the major causes influencing the three-dimensional morphology of Ocypode crab burrows. Although there are plenty of studies on burrow morphologies, no studies have yet studied the energetics of the burrow excavation as a potential factor influencing the burrow morphology, at least for the ghost crabs. In the present study, we collected data of Ocypode crab burrow morphologies from Chandipur, the eastern part of India to identify the nature of morphological complexity (diameters, inclinations, orientation, length and depth, and three-dimensional morphology) and interpret how the burrow morphology is affected by several abiotic factors at Chandipur coast.

The present study was conducted at Chandipur $\left(21^{\circ} 27^{\prime} 45.17^{\prime \prime} \mathrm{N}, 87^{\circ} 3^{\prime} 21.57^{\prime \prime} \mathrm{E}\right)$ near the confluence of the river Burahbalang with the Bay of Bengal (Figure 1). The coastal area of Chandipur is characterized by a wide 


\section{RESEARCH COMMUNICATIONS}

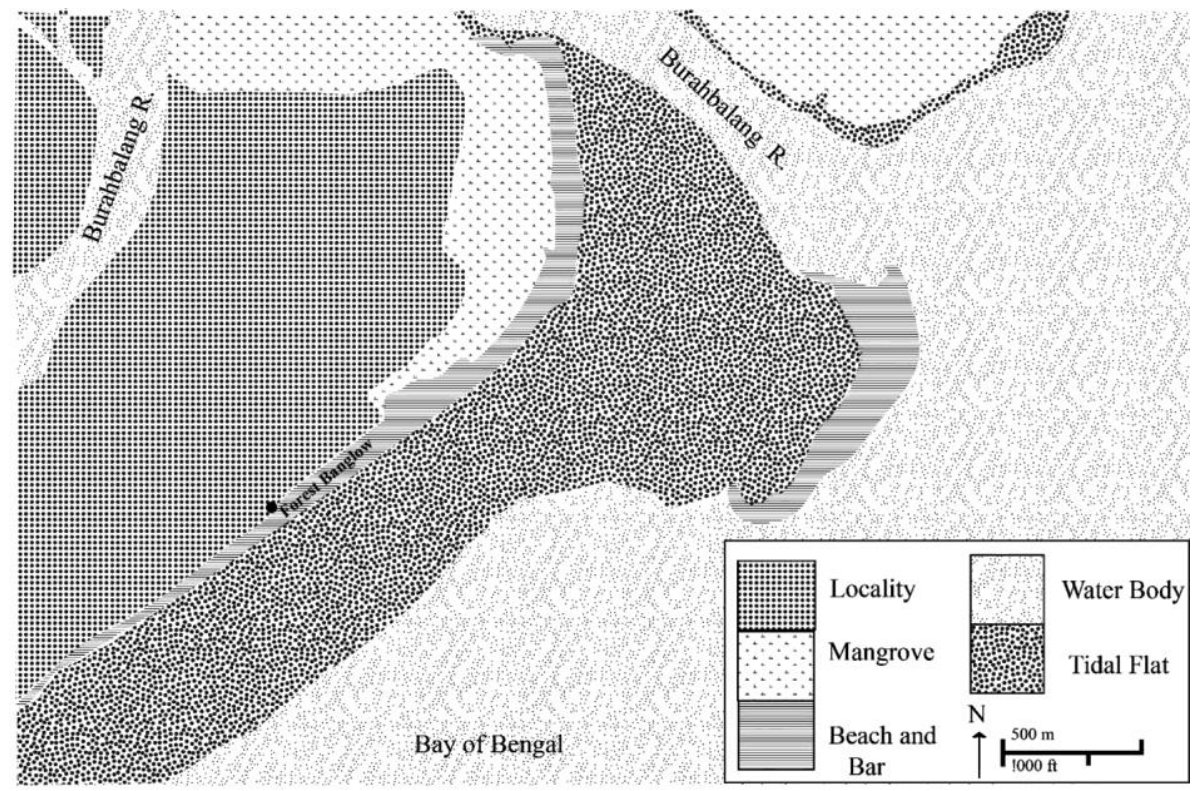

Figure 1. Map of the studied locality with representative sedimentary facies is shown. At the confluence of River Burahbalang and the Bay of Bengal, a drowned estuary has formed and the open sea is beyond the distal bar.

$(\sim 4 \mathrm{~km})$ intertidal flat with a narrow $(\sim 70 \mathrm{~m})$, sandy beach. The ocean-facing, gently inclined intertidal siliciclastic mudflat (seaward slope is $1^{\circ}-3^{\circ}$ ) has a mesotidal setting with semidiurnal tides (tidal range is from $1.87 \mathrm{~m}$ to $4.89 \mathrm{~m})^{18,19}$. Landward of the flat, is a narrow sandy beach, about $3 \mathrm{~km}$ long. The foreshore region of the beach extends from the tidal flat up to the landward limit of wave propagation (Figure 1). The average width of this foreshore region is $\sim 20 \mathrm{~m}$ and the slope is about $5^{\circ}-6^{\circ}$. Behind the foreshore, up to the Aeolian supersurface, the backshore has an average width of 30-35 $\mathrm{m}$ (with a seaward slope near $6^{\circ}-8^{\circ}$ ).

The beach region of Chandipur is infested with numerous burrows made by Ocypode ceratophthalma (Pallas, 1772). Along with it, a rich ecosystem is represented by high ecological interactions on diverse and abundant molluscan assemblages ${ }^{20-24}$. This high biodiversity is probably because of the rich food supply from the nearby Burahbalang river. Other than food, the low turbulence of water and tide-dominated coastal system also support the high crab density. Mainly because of these factors, but together with an appropriate range of water temperature (average temperature varies from $22.2^{\circ}$ to $32.6^{\circ}$ ) and salinity (32.25-27.30\%) (ref. 25), Ocypode crabs are found throughout the beach-barrier bar-mangrovedominated system at Chandipur.

The morphologies of crab burrows differ mainly in diameter, orientation, angle of inclination, depth, complexity and volume. At Chandipur, selected morphological data were collected near a forest bungalow (Figure 1). Because anthropogenic activities can influence the behaviour of these crabs ${ }^{13,26,27}$, our study area was selected to be at least one $\mathrm{km}$ away from the tourist-populated beach area of Chandipur. For each burrow, three types of measurements were taken: (1) burrow diameter, (2) orientation of burrow shafts, i.e. the angle between the horizontal projection of the burrow and the north direction, to get idea on the orientation of the burrows with respect to the shoreline ${ }^{13}$ and (3) inclination of burrow $(\theta)$, i.e. the angle between the burrow and its horizontal projection (more the inclination, the more it is vertical).

In addition, 12 burrows along the beach were cast using bee-wax (see ref. 13). This wax is used for casting because of its easy availability, low cost and easy recyclability. The hard wax was melted into liquid wax by heating in a fire oven. This molten wax was poured into selected burrows. The burrow casts were carefully taken out after hardening of the wax. Each burrow cast was washed, cleaned and photographed. Along with it, several burrow-related data were collected: (1) three-dimensional morphology, i.e. shape, (2) location of the burrow (foreshore versus backshore), (3) burrow diameter measured at the surface where it is exposed, (4) burrow volume, (5) curved length, (6) maximum depth and (7) depth of horizontal shaft (i.e. depth after which the burrow shaft becomes sub-horizontal), along with orientation. Burrows covering the entire range of diameter located at the foreshore and backshore beach were chosen for casting (Table 1). Along with it, a general observation was made to document the nature of the substrate, and the variation in the moisture content of the sediment with depth. Moreover, video graphics observation was recorded to document the overall burrowing processes (Supplementary video $\mathrm{S} 1$ ). 
RESEARCH COMMUNICATIONS

Table 1. Data of burrow morphology extracted after burrow casting indicate that burrow diameter is positively correlated with burrow volume, but not with shape of the burrow

\begin{tabular}{|c|c|c|c|c|c|c|c|}
\hline $\begin{array}{l}\text { Burrow } \\
\text { number }\end{array}$ & Shape & Sub-locations & $\begin{array}{l}\text { Diameter at } \\
\text { surface }(\mathrm{cm})\end{array}$ & Volume (ml) & $\begin{array}{c}\text { Curved } \\
\text { length }(\mathrm{cm})\end{array}$ & $\begin{array}{l}\text { Maximum } \\
\text { depth }(\mathrm{cm})\end{array}$ & $\begin{array}{c}\text { Depth of horizontal } \\
\text { shaft }(\mathrm{cm})\end{array}$ \\
\hline 1 & $\mathrm{~J}$ & Backshore & 3.8 & 660 & 60 & 50.5 & 46.4 \\
\hline 2 & $\mathrm{~J}$ & Midshore & 3.6 & 530 & 68.5 & 35.8 & 30.2 \\
\hline 3 & $\mathrm{Y}$ & Backshore & 6.4 & 940 & 83.2 & 75.8 & NA \\
\hline 4 & $\mathrm{f}$ & Backshore & 6.9 & 900 & 55.6 & 53.0 & NA \\
\hline 7 & I & Foreshore & 2.2 & 10 & 5.3 & 5.3 & NA \\
\hline 8 & I & Foreshore & 1.9 & 10 & 9.3 & 9.3 & NA \\
\hline 9 & $\mathrm{Y}$ & Foreshore & 1.7 & 17 & 10.2 & 11.9 & NA \\
\hline 11 & I & Midshore & 1.6 & 625 & 45.4 & 42.0 & NA \\
\hline 12 & $\mathrm{U}$ & Midshore & 6.5 & 1000 & 47 & 35.8 & 33.3 \\
\hline
\end{tabular}

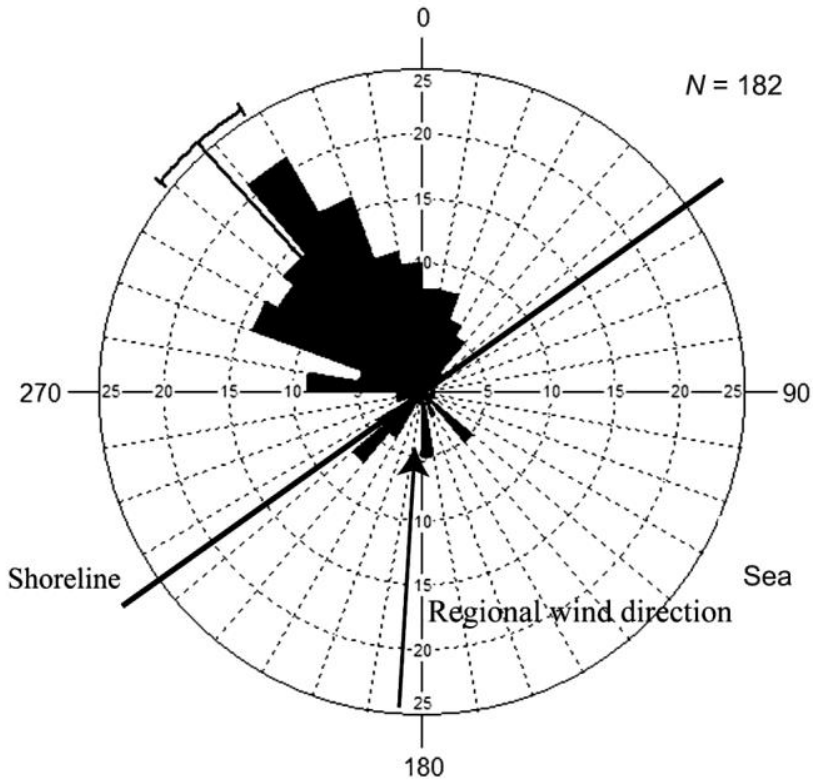

Figure 2. Rose diagram showing orientation of burrows with respect to the shoreline and the regional wind directions.

Finally, we conducted several statistical analyses to understand the nature and behaviour of the ghost crabs at Chandipur. If burrow diameters are dependent upon several biotic and abiotic variables, burrow diameters at different positions of the beach should be significantly different (null hypothesis); an idea tested using a $t$-test with a significance level of $\alpha=0.05$. Similarly, if burrow morphology is a function of different variables, we should expect a non-random distribution of burrow orientation with respect to the sea. To test that idea, 182 burrow orientations were plotted in a rose diagram, using Oriana (version 4.1) (Figure 2). Furthermore, burrow diameters were plotted against their inclinations to their interrelationship.

Foreshore and backshore burrow diameters differed significantly ( $t$-test, $P<0.05$ ), supporting the proposed null hypothesis. The mean foreshore burrow diameter was $1.79 \mathrm{~cm}$ and for backshore burrows, the diameter was $4.24 \mathrm{~cm}$. There was a small overlap of foreshore and backshore burrow diameters in the $3-4 \mathrm{~cm}$ range (Table 1, Figure 3). Burrow diameters larger than $4 \mathrm{~cm}$ at the foreshore regions and smaller burrows $<1 \mathrm{~cm}$ in diameter at the backshore region were scarce. Spatially, burrows were non-randomly oriented along NNW-SSE direction (Chi-square test, $\chi^{2}=133.09, P \square 0.05$ ). The average burrow orientation was $295^{\circ}$. Among these, $81.87 \%$ burrows were perpendicular $\left( \pm 5^{\circ}\right)$ to the local shoreline with the burrow shaft oriented towards the land. Few of the burrow shafts $(18.13 \%)$ were oriented towards the sea (Figure 2).

We found burrow inclination to be highly variable $\left(55.95^{\circ} \pm 12.25^{\circ}\right)$. Burrow diameters showed a negative correlation ( $r=-0.72, P \square 0.01)$ with burrow inclinations. Burrows with an intermediate diameter $(3-6 \mathrm{~cm})$ showed more variation in inclinations compared to the overall trend. When the burrow diameters were very small (1$2 \mathrm{~cm})$, they were nearly all close to vertical (Table 1).

Morphologically, burrows were highly diverse and shapes varied from simple $I$ and $J$ to $U$ and $Y$ types (Figure 4). In terms of spatial distribution across the shore, foreshore burrows were simpler in morphology and had less burrow volumes (Table 1). In contrast, backshore burrows were complex in form and had greater burrow volumes (Table 1). We found that burrow volume was independent of the three-dimensional complexity; hence burrow diameter can reliably be used as a proxy of burrow volume, therefore energetics (Spearman rho $=0.66$, $P=0.02$; Table 1).

At Chandipur, backshore burrow diameters were larger than those of foreshore burrows $(P<0.05)$. This kind of spatial variation of burrow diameter has also been reported by other works on the Ocypode crab burrows (e.g. refs 5, 8, 9, 11, 13). Burrow diameters are correlated with crab carapace lengths $s^{5,7,28}$, simply because larger 


\section{RESEARCH COMMUNICATIONS}

crabs reside in larger burrows (but see ref. 32 for another view). Larger, consequently older crabs may also prefer to live in the backshore merely to avoid competition with younger crabs ${ }^{13}$. However, we found a significant number of foreshore Ocypode burrows with diameters $>3 \mathrm{~cm}$ and also some smaller burrows with diameter $<2 \mathrm{~cm}$ on the backshore. These may indicate migration of crabs in response to tidal activity. Our study was conducted during a neap tidal time, which could be a potential reason for this observation.

The variation in three-dimensional burrow morphology has been reported for a number of ghost crab spe$\operatorname{cies}^{2,8,9,11,13}$. These studies showed that the burrows made by the juveniles were either I, J or U shaped, whereas those of the adults showed greater variability including $\mathrm{Y}$ and spiral configurations ${ }^{8,9,11,29}$. Now, if juveniles reside inside $\mathrm{I}, \mathrm{J}$ or $\mathrm{U}$ burrows, they could simply construct larger burrows of same morphologies when they become

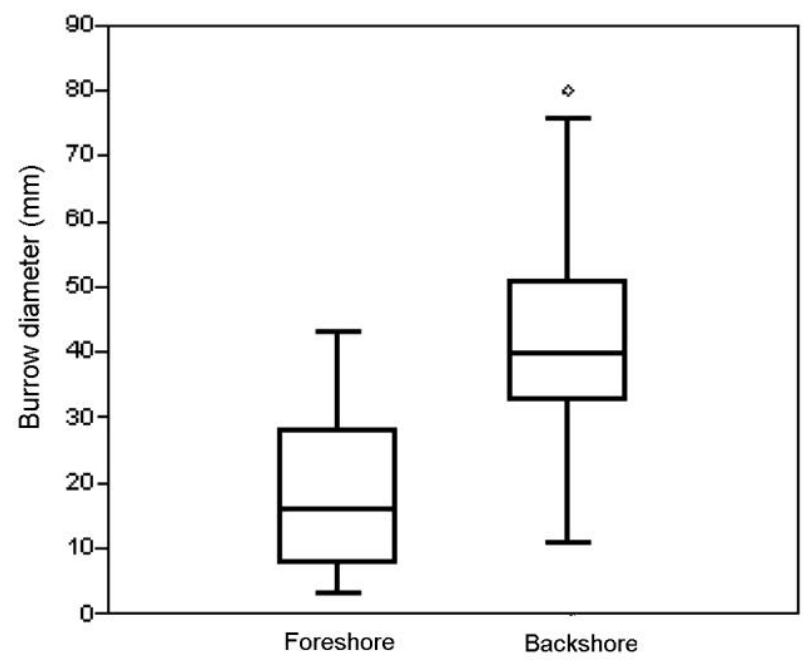

Figure 3. Variation in burrow diameter shows that the foreshore burrow is always smaller than the backshore burrow, although there is considerable number of medium-sized burrows both in the backshore and in the foreshore.

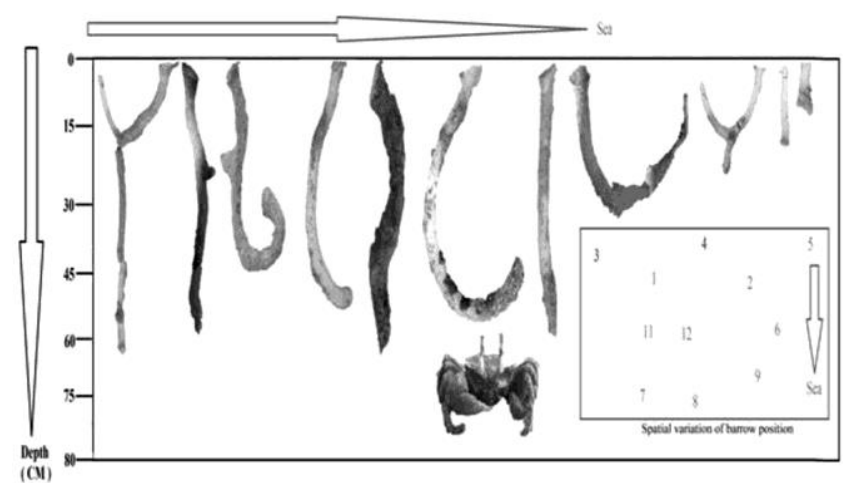

Figure 4. Variation in depth and morphology of burrows with respect to the coast line and depth are shown. Note, shape of the burrow is random, irrespective of burrow locations as shown in the inset. Numbers in the inset are detailed in Table 1. adults, instead of making more complex $\mathrm{Y}$ burrows in their late ontogeny. There are many biological and environmental explanations of this kind of spatial variation in burrow morphology, although the actual reason still remains controversial ${ }^{8}$.

It has been proposed that crabs construct Y-shaped branched burrows where the branch acts as 'back door' in case of burrow collapse during rising tide or to escape from predators $8,10,13$. However, if predation was the only reason, we should have found $\mathrm{Y}$ burrows more preferentially at the foreshore region where burrows are shallower and therefore within the reach of predators (e.g. birds). Moreover, backshore burrows should never be Y-shaped, as the predators can never get access to a resident living inside these larger and deeper burrows. In a similar argument, branches are also not meant to escape during burrow collapse, as most branches remain blind and not open to the surface ${ }^{8}$. This does not indicate that escape from burrow collapse has no role to play in burrow branching, but other factors play a greater role behind this. It has been seen in previous studies that, during low tides, crabs initiate burrowing with simpler I forms and gradually modify the shape of the burrow into complex forms $(J, Y, U)$ while extending them downwards ${ }^{10,11,29}$. Here, we add another plausible explanation in favour of more frequent $\mathrm{Y}$ burrows at the backshore region: Y-shaped burrows may form when a newly excavated $\mathbf{J}$ or I burrow is connected to an existing I or J burrow simply because burrows at the backshore do not get destroyed as easily as foreshore burrows, under the influence of rising tide. More experimental and observational data are required to testify these hypotheses.

However, one pattern prevailing is that, burrow depth was highest farthest from the sea ${ }^{5,12,30}$ (Table 1). As discussed above, these deeper burrows are not excavated simply to avoid predation. Moreover, unless extremely required, there is no point in wasting important metabolic energy to excavate such deeper burrows. It has been proposed that smaller crabs residing at the foreshore have small gills and need to renew water for respiration frequently ${ }^{12}$. For this reason, they make temporary smaller and shallower burrows, so that they can simply abandon them and can return to the sea for recharge of respiratory water $^{8,13}$. In contrast, larger crabs with bigger gills make more permanent, deeper and larger burrows. However, while the depth is not random, it has been proposed that they excavate larger and deeper burrows to reach the groundwater level in order to minimize the risk of desiccation $^{8,13,29,31}$. It is in fact found that, the surrounding sediment temperature decreases drastically from the surface at the burrow opening to the deeper parts of the burrow that have more moisture suggesting the above mentioned hypothesis.

At Chandipur, burrows showed shoreline perpendicular orientation. Preferred orientation for burrows is explained differently for different organisms (e.g. chemical cues 


\section{RESEARCH COMMUNICATIONS}

and the position of the sun for Ocypode $\operatorname{crabs}^{32}$; and magnetic sensitivity, for spiny lobsters ${ }^{33}$ ). Chakrabarti ${ }^{13}$, reported near perpendicular-to-shore burrow orientations of Ocypode crabs in two study locations at Gopalpur, but orientation oblique to the shoreline in another location. He suggested that the wind direction influenced the orientation of burrows. However, we found no correlation between the north-south regional wind direction and the burrow orientations (Figure 2), suggesting that burrow orientations are independent of the prevalent wind direction. Instead, we found that the typical orientation may be related to the direction of the approaching sea water. If the burrows are perpendicular to the shoreline and oriented opposite to the sea direction, sea water can have a less destructive effect on the burrows. In such settings, wave speed will be dampened while water glides along the burrow slope. If the burrow orientation would have been in any other direction (i.e. towards the sea), the wave would have directly hit the opposite burrow wall and made it unstable. If the burrows are oriented towards the sea at an angle $\theta$, that shortens the effective distance (defined as the distance where sea water first hits the burrow wall) (Figure $5 a$ ). Let us say, if the burrow diameter is $d$, and inclination is $\theta, \mathrm{d} h$ height fall of water in the vertical direction will lower the horizontal distance by $\mathrm{d} h \tan \theta$. Hence the effective distance becomes $(d-\mathrm{d} h \tan \theta)$, which is less than $d$ (as $\mathrm{d} h \tan \theta>0)$. Due to shortening of effective distance, sea water can hit the
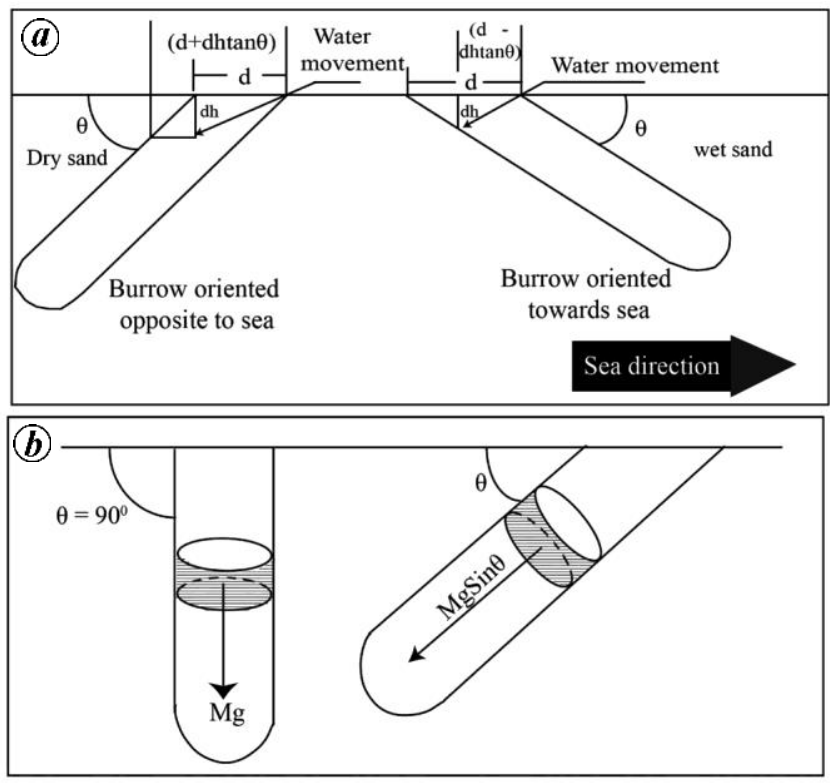

Figure 5. $\boldsymbol{a}$, Schematic drawing of burrow morphology showing the variation of effective distance (see text) as a function of shaft orientation. It increases when burrows are oriented towards land and decreases when they are in the seaward direction. It also shows how seaward orientation of burrows can be important for their stability. Seaward burrows have to support wet which is not a very viable for burrow stability. $\boldsymbol{b}$, Variation of magnitude of force during excavation of an inclined burrow and a vertical burrow. burrow wall quickly and an impact of the water body with the burrow wall can cause maximum damage. On the other hand, when burrows are oriented towards the land, the effective distance will be $(d+\mathrm{d} h \tan \theta)$. Less is the $\theta$, more is the effective distance, and the time of impact with the burrow wall is also increased. This dampens the velocity of water, and the impact is not of high magnitude, with the burrows being in a much stable position than the previous case.

Another potential reason behind this preferential orientation involves sloping of the sides of the excavation to the angle of repose. The angle of repose is a good gauge for estimating the angle of shear planes in the sediment profile. Shear planes are the lines through which the unexcavated sediment forming the excavation walls may break. The angle of repose for dry sand is $34^{\circ}$ and the same measures $45^{\circ}$ in case of sand with a small addition of water in it. When a certain degree of water is present in sand, then it acts like a plastic substance and the degree of plasticity depends upon the relative amount of water and sand ${ }^{34}$. Besides the small addition of water in sand being able to bridge the gaps between grains, the resulting electrostatic attraction of water between grains increases the angle of repose. Since the burrows are devoid of any lining in muddy sediment, compaction of the walls serve a similar action in case of clay-rich sediment in foreshore region. As proposed by a study ${ }^{35}$, crabs cannot maintain larger burrows with greater burrow diameters in soft, fluid-rich sediment, because of the high probability of burrow collapse (also, ref. 36). This view supports the idea of making a small burrow in the foreshore region. As the tide rises, seawater percolates through and wets the highly porous siliciclastic sand. If burrows were oriented seaward side, the weight of wet sand will be on the burrow. On the other hand, orienting opposite to the sea, relatively drier sand can provide better stability because of its lesser weight than that of wet sand (Figure $5 a$ ). This type of control of the nature of sediments and associated fluids on burrow stability and therefore the distribution and size, suggests that abiotic factors can significantly influence burrow morphologies $^{16,17,35-38}$.

Finally, along with these abiotic controls, the morphology of burrows can also be controlled by crab energetics: larger crabs need to dig larger burrows; so they have to excavate more volume of sediment. If it was done vertically, to excavate a certain volume of sediment of mass $m$ would require $m g$ ( $g$ is the gravitational acceleration) amount of force. Instead of digging it vertically, if the process of excavation is done at an inclined angle, for the same amount of sediment, the force required is $m g \sin \theta$ ( $\theta$ being the angle of inclination measured in the field), which is energetically more viable for the organism (Figure $5 b$ ). That is another reason why larger the burrow volume, lower is the inclination value. In comparison, to optimize energy, smaller crabs would have also dug 


\section{RESEARCH COMMUNICATIONS}

inclined burrows. However, smaller burrows are mostly vertical. The reason for such discrepancy is probably the material property of the excavated sand. We have already discussed that smaller burrows are mostly located near the foreshore, where the sediment (a mixture of sand and mud) is watery and heavy. To make a longer burrow in this region, where the sediment is watery and highly cohesive in nature, younger crabs need more energy to excavate a long burrow. Inclined burrow in this heavier sand is more prone to collapse because of its own weight. Moreover, because the foreshore burrows are small in diameter, if they become more inclined, there are chances that they may be exposed to the wave erosion at the foreshore. For all these reasons, both energetic and environmental, foreshore dwellers make vertical burrows. These results indicate that energetics is the primary reason for burrow inclination.

Based on this study, the following conclusions could be made: (1) burrow diameters are negatively correlated to inclination and diameter increased towards the backshore region; (2) backshore large-diameter burrows are deeper so that the groundwater level could be reached to minimize chances of desiccation; (3) burrow morphology is independent of location and burrow diameter; (4) burrow inclination is independent of wind direction but strongly correlated with the direction of the upcoming tide, because inclination and burrow diameter together influence burrow stability; and (5) inclination of the burrow also depends upon crab energetics, i.e. the total amount of energy invested to excavate sediments during burrow construction. All these suggest that different types of abiotic factors like sediment, approaching water level, groundwater and energetics determine the Ocypode burrow morphology ${ }^{13}$. However, detailed, species-specific studies, probably laboratory simulations using angle and orientations as a control of burrow morphology, are always required to identify the pattern of variation in burrow morphologies across different species at different biogeographic locations.

Upon identifying the generalized pattern, these details can be used in ecological and palaeontological reconstructions $^{2,39,40}$. For example, one study $^{9}$ has given a detailed review of how these biological traces could be used to identify paleoshorelines and shore-facies in the geological record. Moreover, systematic study of the distribution of these burrows could be used as a proxy to global sea level change $9,39,41,42$. More details of the usefulness of this ichnotaxa can be found in ref. 43 . However, the study of these coastal ichnotaxa from different parts of the world is essential to identify spatial and species-specific variation in behavioural patterns of these ocypodid crabs so that the result can be used in palaeontological studies.

1. Brown, A. C. and McLachlan, A., Ecology of Sandy Shores, Elsevier, Amsterdam, 1990, 2nd edn.
2. Lucrezi, S. and Schlacher, T. A., The ecology of ghost crabs Oceanogr. Mar. Biol.: Ann. Rev., 2014, 52, 201-256.

3. Weber, F., Nomenclator entomologicus secundum entomologiam systematicam... Fabricii, adjectis speciebus recens detectis et varietatibus. Kiel \& Hamburg, C.E. Bohn., 1795, 8, 172.

4. De, C., Biological reworking of sediments by crabs: a use for erosion of the Digha beach, West Bengal. Curr. Sci., 1998, 75, 617-620.

5. Rodrigues, E., Freitas, R., Delgado, N. D. C. and Soares-Gomes, A., Distribution patterns of the ghost crab Ocypode cursor on sandy beaches of a tropical island in the Cabo Verde archipelago, Eastern Central Atlantic. Afr. J. Mar. Sci., 2016, 38, 181-188.

6. Genoni, G. P., Increased burrowing by fiddler crabs Ucarapax (Smith) (Decapoda: Ocypodidae) in response to low food supply. J. Exp. Mar. Biol. Ecol., 1991, 147, 267-285.

7. Qureshi, N. A. and Saher, N. U., Burrow morphology of three species of fiddler crab (Uca) along the coast of Pakistan. Belg. J. Zool., 2012, 142, 114-126.

8. Chan, B. K. K., Chan, K. K. Yu. and Leung, P. C. M., Burrow architecture of the ghost crab Ocypode ceratophthalma on a sandy shore in Hong Kong. Hydrobiologia, 2006, 560, 43-49.

9. De, C., Neoichnological activities of endobenthic invertebrates in downdrift coastal Ganges delta complex, India: their significance in trace fossil interpretations and paleoshoreline reconstructions. Ichnos, 2000, 7, 89-113.

10. De, C., Biophysical model of intertidal beach crab burrowing: application and significance. Ichnos, 2005, 12, 11-29.

11. Lim, S. S. L., Yong, A. Y. P. and Tantichodok, P., Comparison of burrow morphology of juvenile and young adult Ocypode ceratophthalmus from Sai Kaew, Thailand. J. Crust. Biol., 2011, 31, 59-65.

12. Seike, K. and Nara, M., Burrow morphologies of the ghost crabs Ocypode ceratophthalma and $O$. sinensis in foreshore, backshore, and dune subenvironments of a sandy beach in Japan. J. Geol. Soc. Jpn, 2008, 114(11), 591-596.

13. Chakrabarti, A., Burrow patterns of Ocypode ceratophthalma (Pallas) and their environmental significance. J. Palaeontol., 1981, 55, 431-441.

14. Barrass, R., The burrows of Ocypode ceratophthalmus (Pallas) (Crustacea, Ocypodidae) on a tidal wave beach at Inhaca Island, Mocambique. J. Anim. Ecol., 1963, 32(1), 73-85.

15. Jones, D. A., Aspects of the ecology and behaviour of Ocypodeceratophthalmus (Pallas) and O. kuhlii de Haan (Crustacea: Ocypodidae). J. Exp. Mar. Biol. Ecol., 1972, 8, 31-43.

16. Ringold, P., Burrowing, root mat density, and the distribution of fiddler crabs in the eastern United States. J. Exp. Mar. Biol. Ecol., 1979, 3, 11-21.

17. Takeda, S. and Kurihara, Y., The distribution and abundance of Helicetridens (De Haan) burrows and substratum conditions in a northeastern Japan salt marsh (Crustacea: Brachyura). J. Exp. Mar. Biol. Ecol., 1987, 107, 9-19.

18. Chakrabarti, A., Sedimentary structures of tidal flats: a journey from coast to inner estuarine region of eastern India. J. Earth Syst. Sci., 2005, 114, 353-368.

19. Mukherjee, K. K., Das, S. and Chakrabarti, A., Common physical sedimentary structures in a beach-related open sea siliciclastic tropical tidal flat at Chandipur, Orissa and evaluation of weather conditions through discriminant analysis. Senckenbergiana Mar., 1987, 19, 261-293.

20. Das, A., Mondal, S. and Bardhan, S., A note on exceptionally high confamilial naticid drilling frequency on Natica gualteriana from the Indian subcontinent. Hist. Biol., 2014, 26(6), 758-764.

21. Mondal, S., Bardhan, S. and Sarkar, D., Testability of the energy maximization model (Kitchell et al., 1986) of naticid predation on two bivalve prey from the eastern coast of India. Nautilus, 2010 , 124, 137-150.

22. Mondal, S., Bardhan, S., Mallick, S. and Roy, A., Repair scars on Mactra violacea from the eastern coast of India: a new classification 


\section{RESEARCH COMMUNICATIONS}

and a model for describing shell breakage on bivalves Palaeontol. Electron., 2014, 17, 1-13.

23. Pahari, A., Mondal, S., Bardhan, S., Sarkar, D., Saha, S. and Buragohain, D., Subaerial naticid gastropod drilling predation by Naticatigrina on the intertidal molluscan community of Chandipur, Eastern Coast of India. Palaeogeogr., Palaeoclimatol., Palaeoecol., 2016, 451, 110-123.

24. Paul, J. and Mondal, S., Ecological significance of Ocypode crab burrows: a case study from Chandipur, Eastern Coast of India. National Conference on Earth Sciences in India: Challenges and Emerging Trends, Roorkee, India, 2013.

25. Mohanty, R. K. and Patnaik, P. N., Relative abundance and resource characteristics of penaeid prawn seed in Orissa coast. Indian J. Fish, 2002, 49, 67-72.

26. Barros, F., Ghost crabs as a tool for rapid assessment of human impacts on exposed sandy beaches. Biol. Conserv., 2001, 97(3), 399-404.

27. Yong, A. Y. P. and Lim, S. S. L., The potential of Ocypode ceratophthalmus (Pallas, 1772) as a bioindicator of human disturbance on Singapore beaches. Crustaceana, 2009, 82, 1579-1597.

28. Lim, S. S. L., Fiddler crab burrow morphology: how do burrow dimensions and bioturbative activities compare in sympatric populations of Ucavocans (Linnaeus, 1758) and U. annulipes (H. Milne Edwards, 1837)? Crustaceana, 2006, 79, 525-540.

29. Takahashi, S., On the burrows of Ocypode ceratophthalma Fabricius. Kogaku, 1932, 2, 329-335.

30. Schuchman, E. and Warburg, M. R., Dispersal, population structure and burrow shape of Ocypode cursor. Mar. Biol., 1978, 49(3), 255-263.

31. Hayasaka, I., The burrowing activities of certain crabs and their geological significance. Am. Midl. Nat., 1935, 16, 99-103.

32. Dos Santos, C. M. H., Pinheiro M. A. A. and Hattori, G. Y., Orientation and external morphology of burrows of the mangrove crab Ucidescordatus (Crustacea: Brachyura: Ucididae). J. Mar. Biol. Assoc. UK, 2009, 89, 1117-1123.

33. Lohmann, K. J. et al., Magnetic orientation of spiny lobsters in the ocean: experiments with undersea coil systems. J. Exp. Biol., 1995, 198, 2041-2048.

34. Webster, A. G., On the angle of repose of wet sand. Proc. Natl. Acad. Sci. USA, 1919, 5(7), 263-265.
35. Wang, J. Q. et al., Fine-scale environmental heterogeneities of tidal creeks affect distribution of crab burrows in a Chinese salt marsh. Ecol. Eng., 2009, 35, 1685-1692.

36. Bertness, M. D. and Miller, T., The distribution and dynamics of Ucapugnax (Smith) burrows in a New England salt marsh. J. Exp. Mar. Biol. Ecol., 1984, 83, 211-237.

37. Kneib, R. T., Patterns of invertebrate distribution and abundance in the intertidal salt marsh: causes and questions. Estuaries, 1984, 7, 392-412.

38. Teal, J. M., Distribution of fiddler crabs in Georgia salt marshes. Ecology, 1958, 39, 185-193.

39. Frey, R. W. and Seilacher, A., Uniformity in marine invertebrate ichnology. Lethaia, 1980, 13, 183-207.

40. Radwański, A., Wysocka, A. and Górka, M., Miocene burrows of the ghost crab Ocypode and their environmental significance (Mykolaiv Sands, Fore-Carpathian Basin, Ukraine). Acta Geol. Pol., 2012, 62(2), 217-229.

41. De, C., Environmental significance of the Quaternary lebensspuren of the Banas river basin of Gujarat, India. Indian Minerals, 1995, 49, 13-30.

42. Wilson, M. A., Curran, H. A. and White, B., Palaeontological evidence of a brief global sea-level event during the last interglacial. Lethaia, 1998, 31, 241-250.

43. Nesbitt, E. and Campbell, K. A., The palaeoenvironmental significance of Psilonichnus. Palaios, 2006, 21, 187-196.

44. Frey, R. W., Curran, H. A. and Pemberton, S. G., Tracemaking activities of crabs and their environmental significance: the ichnogenus Psilonichnus. J. Palaeontol., 1984, 58, 333-350.

ACKNOWLEDGEMENTS. J.P. acknowledges C. Talbot (Uppsala University), C. De (GSI), S. Mukherjee (IIT Bombay), S. Bardhan (JU) and D. C. Pal (JU) for discussion. S.M. acknowledges the SERB Fast Track Young Scientists project (SR/FTP/ES-133/2014) and C.U. Departmental Grant for partial funding.

Received 2 January 2019; revised accepted 29 April 2019

doi: 10.18520/cs/v117/i4/699-705 